\title{
尿管腸吻合術後の人工膀胱內壓について
}

新渴大學皮膚科泌尿器科敉室

(泌尿器科主任：楠隆光敎授)

鈴杰

昭

\section{ABOUT THE INTRALUMINAL PRESSURE OF THE ARTIFICIAL URINARY BLADDER FOLLOWING URETERO-INTESTINAL ANASTOMOSIS.}

\author{
Akira Suzuki \\ From the Department of Urology, School of Medicine, Niigata University. \\ (Director: Prof. T. Kusunoki)
}

I have measured the intraluminal pressure by using the ordinary simple cystometer under following 4 different conditions: 1) the artificial ileum-bladder, 2) the artificial sigmoid bladder, 3) the normal rectum and 4) the normal urinary bladder. The results are as the following table.

\begin{tabular}{l|c|c|c|c|c}
\hline & \multirow{2}{*}{$\begin{array}{c}\text { Total No } \\
\text { Tested }\end{array}$} & \multicolumn{2}{|c|}{ Supine Position } & \multicolumn{2}{c}{ Erect Position } \\
\cline { 3 - 6 } & & Resting & Straining & Resting & Straining \\
\hline lleum-bladder & 7 & 1.9 & 5.8 & 5.9 & 9.6 \\
\hline Sigmoid bladder & 4 & 9.9 & 38.5 & 26.5 & 48.0 \\
\hline Rectum & 20 & 12.0 & 58.0 & 24.0 & 74.0 \\
\hline Normal urinary bladder & 10 & 6.0 & 48.0 & 21.5 & 76.3
\end{tabular}

Tab. 1. Average pressure in ileum-bladder, sigmoid bladder, rectum and normal urinary bladder ( $\mathrm{mm}$. of mercury.)

The followings become clear from these data:

1. In the ileum-bladder, the pressure is considerably lower than in the sigmoid bladder or normal rectum. These results coincide strikingly to the fact that the blood electrolyte imbalance occurs far more frequently after ureterosigmoidostomy or sigmoid bladder formation than after ileum-bladder formation. And, I think that the renal damage which is caused by the deleterious effect of high intrarectal preseure, is the cause of blood electrolyte inibalance. As the intraluminal pressure of the ileum-bladder is very low, the effect of the pressure upon the renal pelvis which is transmitted from the ileal segment is negligible. The blood chemistry imbalance which may be caused by the renal damage, has never been observed in all our cases with ileum-bladder formation.

Therefore I believe that the pressure in the bowel in which the ureter is transplanted, will play the very important role for the occurrence of the blood electrolyte imbalance following the uretero-intestinal anastomosis, and the bacterial infections in the bowel are of less 
importance (while the isolated sigmoid bladder is as sterile as the ileum-bladder, the former is remarkably more balanced than the latter in blood chemistry).

2. The normal intravesical pressure and the normal intrarectal pressure shown on Tab. 1, are values at the volume of $300 \mathrm{cc}$. The intravesical pressure is considerably lower than the latter in various condition. But the former rises as high as the latter on straining in the erect position, which makes us consider that the structure of the ureteral orifice is important to prevent the free transmission of intravesical pressure to the renal pelvis.

Accordingly, the low pressure is particulary significant in the artificial urinary bladders which have no such structures of their ureteral orifices as normal bladders.

一般外科學及び化學療法の進步によつて，手術 そのものは非常に安全度を增した尿管腸吻合術

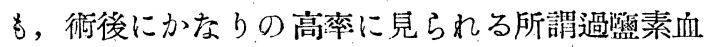
性酸性症を主症狀とする血液電解質不平衡のため に，術後の患者の生存期間の䍐いの外に短い場合 が相當に多いと言う點で，今日でも檢討すべき問 題が殘されている.そしてこの點を如何に工夫し て患者の生年月を延すかが，本手術の存在價值 を高める點て大切である。

本手術後に發生する血液電解質の不平衡は, 主 として末梢細尿管部の機能障碍によるものとされ ているが，その原因として最近では上行性細菌感 染と共に吻合部腸內壓が異常に高いことが重要視 され出した. 郎ち Kekwick, Paulley, Riches and Semple, Korenberg 等がその主張者で，又噪床的 にも Whisenand and Moore は47歲の女子の腎

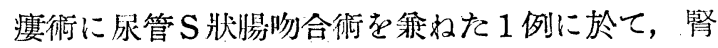
瘦管から粪便及び瓦斯の排出を見ており，Mathis は本手術術後に自發泩氣骼腎盂レ線像を見, 又 Baker and Miller は 7 例の脉管 S 爿腸吻合術の症 例の中 5 例に於て造影娳を道腸內に注入して，そ の內壓がまだ排便感を起さない程度に低い時期に 既に造影劑の.上部疗路への，逆流を證明した等と S 狀腸內壓が尿路內壓よりも常に非常に高い事を示 している事實が續々撥表されている. しかしBoy-

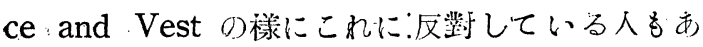
る.

私はこの本手術後の血液電解質不阳衡已腸內壓 との關係を臨床例に就りて憸討した。 そして術後 血液電解質の最も安定している备腸膀胱に於て伵
腸內壓が極めて低いのに反して，その不安定な尿 管 S 狀腸吻合術後に於て S 狀腸內厚は相當高壓て ある事をたしかめ得て，吻合部腸內壓の如何が術 後の血液電解質平衡に非常に大きい影響のあると 言う興味ある事實を確め得た。. 茲にその成績を述 ベんとするものである.

\section{I. 尿管腸吻合術後の血液電解質 不平衡に就て}

この問題は呚室の阿部㣂男が佃究しており，そ の詳細は阿部が發表する筃であるが，私の檢查成 績を迅べる先だつてこの點に就ても說明する必 要があるので，簡單に說明する。

新大泌辰器科教室で施行した尿管腸吻合術の症 例34例に就ての調枯に上れば，19例，㴧ち55.8\%

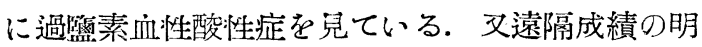
確な49例に就て見ると，8例に，師ち $16.3 \% に$ 術 後 1 カ月から 1 年前後の間に電解質不平衡による 死亡例を見ている.これは總括的成績であるが， 吻合腸管部の異るるのを別々に分けて見る之，そ の成績が非常に異るのである，郎ち，普通の尿管

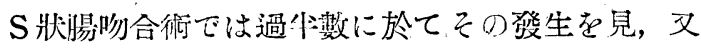
25\%の高率にそのための犧牲を見ており，䀧置し た S 狀腸に尿管を吻合した S 狀腸膀胱でも同樣に 殆んぞその全部にその不平衡を見，20\%の高率に 㚡牲を見ておるのに對して，伵腸膀胱では13例の 凡てに全く電解質の不平衡を見す，又そのための 犧牲す1例をなかつた。この成績は公く最近アメ リカから Mersheimer, Kolarsick and Kammandel 及び Mc Lean and Fais が動物實驗で, 又 Eiseman and Bricker, Bricker 及び Klinge が 
臨床例で 經驗している成績と一致するものであ る. そして我々の教室ではこの朋腸膀胱の成績の よい原因を各方面から检討しているか，私はその 一部として腸內壓を测定した。

\section{II. 檢查方法}

1. 测定裝置

私は內壓测定に自家考穼になる單礼な膀胱內壓 测定器を使用した. それは第 1 圖に示す樣な测定 器で, 次の㨾な部分からなつている. 郎ち, $\mathrm{A}$ ： 水銀マ; メー夕, B：三栓辦(空氣䛯節用), $\mathrm{C}$ : 空匊室, $\mathrm{D}$ ：三栓瓣， $\mathrm{E}$ ：膀胱內に㨂入したカテ ーテルに接續す，F：注入器に接旈する. G：零 點.

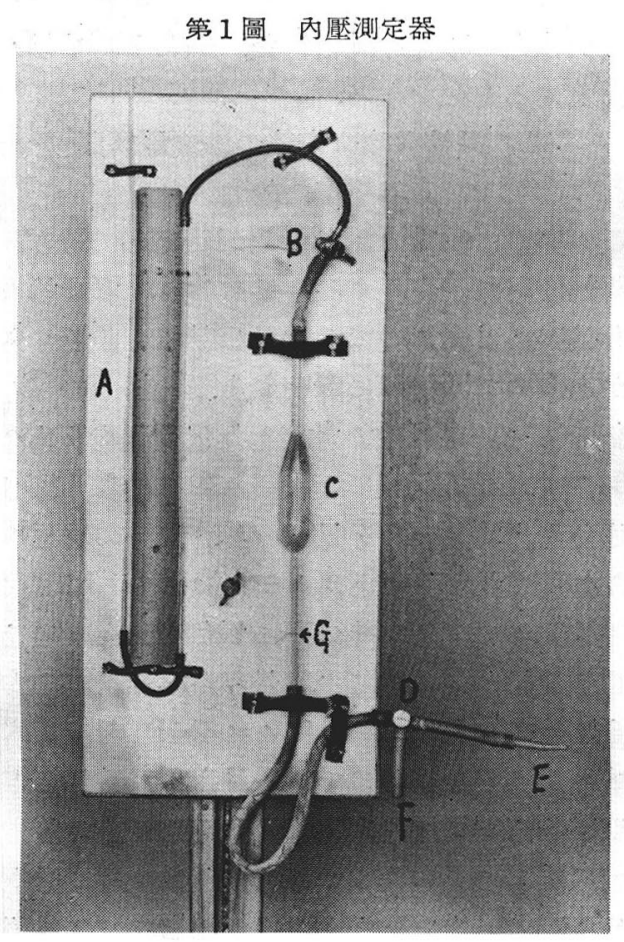

2. 测定方法

（イ）患者の骷位 水平背位及び立位に於て，平 常呼吸時及び加腹壓時の內壓を测定した. 直腸內 壓では排便筋も作用せしめた。

(口) 注入液 適溫の隇菌水を用いた。

(八)注入速度 容量 $500 \mathrm{cc}$ のイルリガトールを $1.7 \mathrm{~m}$ の高さに固定して注入した.
（二）测定值の詯み 物指しが 2 倍に目盛つてあ るので讀んだ值がそのまう壓力となる.

牫腸膀胱では後で述べる如く，內壓が非常に低 いために水柱で测定するのが適當と考えられた が，同時に膀胱及び直腸內壓をも测定して，比較 するに便利な樣に矢張り水銀マ广メーターを用い た.

\section{3. 實施要領}

（イ）越腸膀䏙

被检者を水平仰卧せしめ, 趣晹膀胱開口部より 秒ら小さい直徑のネラトン氏カテーテルを捚入し て內容を完全に除去し，次に滅菌水を注入して， その溢れ出るまでの量を测定して容量とした。 そ の後暫く岀靜を保たせると, 餘分の水は溢流して 平常時と同じ狀態になる.この間に零點を备腸廔 部にして, 测定器を調節しておく.そこで测定器

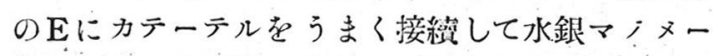
ターの讀みを見る。次に腹壓を加えさせて测定す る.この際內容は一部流出するが, 私の檢枯目的 に對して垩支えない，更に立位に於て同樣の事を 繰り返した. かくして得た傎は篇密に云えば水力 學的の袱正を要すべき性質のものであるが, 問題 が複雜になるので，私はこの實测值をそのま〉使 用することとした。 又测定時には，太いカテーテ ルを使用すると婜孔部が完全に開塞されて高壓值 が得られるがここれ平常時と異つた狀態になる ので, 瘦孔部を閉塞しない程度の太いカテーテル を使用した。

（口）臬腸及び S 狀晹

a. 正常人の淔腸內涯を测定する場合には，檢 植前に排便せしめ, その後腸洗滌を行つて直腸內 を空虚にしておく．次いで肚門カテーテルを直腸 に挿入して测定器わにE接縕する. 更にイえリガ トールからの管を Fに接纉し10乃至 $20 \mathrm{cc}$ 注入して Dを開いて空亊室と連絡せしめ, 测定器を上下し て零點を肍阿の高さに合わせ， B を閉ぢて空半室 を遮斷する.その後は $50 \mathrm{cc}$ 宛斷緢的に注入して內 壓を测る. 總量 $30 \mathrm{Ccc}$ 注入後に腹壓を加えて排便 する要领で力まかせて々の內壓を测つた. 同樣の ことを立位で行つた.この值も肬腸膀胱の場合之 
第 1 表 赹腸膀脱例に於ける內厭測定值

\begin{tabular}{|c|c|c|c|c|c|c|c|c|c|c|c|c|c|c|}
\hline \multirow{3}{*}{ 番號 } & \multirow{3}{*}{ 氏 } & \multirow{3}{*}{ 名 } & \multirow{3}{*}{ 性 } & \multirow{3}{*}{ 年齡 } & \multirow{3}{*}{ 臨 床 診 斷 } & \multicolumn{5}{|c|}{ 闻腸膀胱丙壓 (mmHg) } & \multicolumn{4}{|c|}{ 直腸內壓 $(\mathrm{mmHg})$} \\
\hline & & & & & & \multirow[b]{2}{*}{$\begin{array}{l}\text { 容量 } \\
\text { (cc) }\end{array}$} & \multirow{2}{*}{\begin{tabular}{|c|} 
背 \\
靜常時
\end{tabular}} & \multirow{2}{*}{$\begin{array}{l}\text { 位 } \\
\text { 加腹 } \\
\text { 厭時 }\end{array}$} & \multicolumn{2}{|c|}{ 立 位 } & \multicolumn{2}{|c|}{ 背 } & \multicolumn{2}{|c|}{ 立 位 } \\
\hline & & & & & & & & & 靜常時 & $\begin{array}{l}\text { 加腹 } \\
\text { 厭時 }\end{array}$ & 靜常時| & $\begin{array}{l}\text { 加腹 } \\
\text { 暦時 }\end{array}$ & 靜常時 & $\begin{array}{l}\text { 加腹 } \\
\text { 厭時 }\end{array}$ \\
\hline 1 & 橫C & & $\hat{\delta}$ & 81 & 前立腺癌 & 85 & 2.0 & 7.0 & 9.0 & 9.0 & 8.0 & 30.0 & 24.0 & 55.0 \\
\hline 2 & 佐( & & $\hat{o}$ & 56 & 膀腃乳頭腫性癌 & 60 & 1.5 & 7.0 & 7.0 & 9.0 & 10.0 & 27.0 & 25.0 & 45.0 \\
\hline 3 & 佐O & & $\hat{o}$ & 62 & 膀 胱 癌 & 70 & 4.0 & 6.0 & 4.0 & 11.0 & 25.0 & 85.0 & 28.0 & 95.0 \\
\hline 4 & 長O & & 웅 & 47 & 子宮癌 & 25 & 0 & 3.5 & 5.0 & 12.0 & 10.0 & 17.0 & 23.0 & 23.0 \\
\hline 5 & 成 0 & & q & 56 & 膀胱腟瘦 & 60 & 1.5 & 4.0 & 5.0 & 12.0 & 12.0 & 19.0 & 17.0 & 26.0 \\
\hline 6 & 新 0 & & o & 47 & 膀胼癌 & 50 & 3.0 & 6.0 & 4.0 & 7.0 & 10.0 & 27.0 & 27.0 & 47.0 \\
\hline 7 & 小० & & $\hat{0}$ & 61 & 膀胱 癌 & 60 & 1.0 & 7.0 & 7.0 & 7.0 & 12.0 & 47.0 & 22.0 & 54.0 \\
\hline 平均値 & & & & & & 61 & 1.9 & 5.8 & 5.9 & 9.6 & 10.6 & 30.6 & 22.9 & 43.5 \\
\hline
\end{tabular}

$\mathrm{S}$ 狀腸㾴を設けた $\mathrm{S}$ 狀腸膀胱例

\begin{tabular}{l|c|c|c|c|c|c|c|c|c|}
8 & 淸 & 9 & 44 & 子 宮 癌 & 70 & 6 & 10.0 & 9.0 & 13.0
\end{tabular}

訨：尿管腸吻合はいづれも Kerr-Colby-Coffey II法による

同樣に，水力學的補正なしに使用する事とした。

b. 曂置した直腸膀胱に於ては測定要領は前者 と同樣で，前處置は必要ない。大體日常の排便感 之同程度の感覺を起し得る容量で測定した.

(八) 膀 腅

膀胱內壓の測炎は大體佐藤誠の方法に準じた. この際その值は背位と立位では相當に異るもので あるが，私は日常生活という點をも考慮し，他の 測定值と比較檢討するという意味で背位と立位と 兩方の場合に測定した.

\section{III. 檢查成績}

\section{（イ）域腸膀胱}

趣腸膀胱の 7 例に就て 趈腸膀胱及び直腸の內壓 灻背位及び立位で測定した。そ成績は第 1 表の 如くである. 郎ち，その平均值が伵腸膀胱では背 位正常時に $1.9 \mathrm{mmHg}$ で直腸內 $10.6 \mathrm{mmHg}$ よ 1)も極めて低い，更に注目すべきは，直腸內壓は 背位加腹壓時に $30.6 \mathrm{mmHg}$ ，立位靜常時に 22.9 $\mathrm{mmHg}$ ，及び加腹壓時に $43.5 \mathrm{mmHg}$ 之日常生活 時の種々の狀態で階段的に高くなるのに對して, 廻腸膀胱內のそれは夫々 $5.8,5.9 .9 .6 \mathrm{mmHg}$ と 餘り高くならない。

郎ち，最高の立位加腹壓時の 值である $9.6 \mathrm{~mm}$ $\mathrm{Hg}$ さ气も直腸內壓つ最低の背位靜常時の $10.6 \mathrm{~mm}$ $\mathrm{Hg}$ よりも低いのである。この內壓の低い原因は， 尿管から流入した尿が趣腸內に溜らないで，次か ら次えと腸廔部から流出して終うためであつて，
Klinge and Bricken (1953) は臨床例に於て腸瘦 部からの尿の流出注周期的にその容量の56 63\% を，殆んぞ一定した量づつ排出されることを確め ている. 更に興味ある事は, 廣範圍に進んだ子管癌 のをめに膀胱及び值腸に癌浸潤の波及した 1 例に 於て人工肘門と共に，趣腸膀胱と同樣の形式で $\mathrm{S}$ 狀腸の一部を曂置してこれに兩側尿管を吻合し, $\mathrm{S}$ 狀腸瘦を腹壁に置いてから，そのS 狀腸膀胱の 內壓を測定して見な. その值は第 1 表に示す第 8 例であるが，普通の直腸內壓よりは遥かに低值で はあるが，一般に越腸膀胱の本均值を上廻る值で あつた。この事實は人工膀胱の形，位置的關係に よつて偶然得られたるのかも知れないが，一面 $\mathrm{S}$ 狀腸內壓が趣腸のそれより生理的に高く，その狀 態がそのまつ殘つているとも考えられる.

（口） S 狀腸膀胱

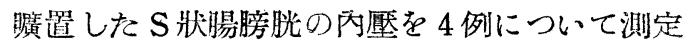
した. その值は第 2 表の如くである.

師ち，その本均值は背位靜常時 $9.9 \mathrm{mmHg}$, 加 腹壓時 $38.5 \mathrm{mmHg}$ ，立位靜常時 $26.5 \mathrm{mmHg}$ 及び 加腹壓時 $48.0 \mathrm{mmHg}$ は越晹膀胱症例の直腸內壓 と全く同樣に，靜常時に既に高いものが，立位及 び加腹壓により急激に上景している。

直腸內壓浱一般に膀腃內壓より非常に高壓ざあ るとされているが，その實測值の報告には餘り接 していない，私が調查したところでは，Hurst 文 び Best and Taylor の報告を探し得たにとぼま 
第 2 表 $S$ 狀腸膀腅內厗測定値

\begin{tabular}{|c|c|c|c|c|c|c|c|c|c|c|}
\hline \multirow{2}{*}{ 番號 } & \multirow{2}{*}{ 氏 } & \multirow{2}{*}{ 名 } & \multirow{2}{*}{ 性 } & \multirow{2}{*}{ 年菊命 } & \multirow{2}{*}{ 臨 床 診 斷 } & \multirow{2}{*}{$\begin{array}{l}\text { 容 } \\
\text { (cc) }\end{array}$} & \multicolumn{2}{|c|}{ 背位 $(\mathrm{mmHg}$ ) } & \multicolumn{2}{|c|}{ 立位 $(\mathrm{mmHg})$} \\
\hline & & & & & & & 靜常時 & 加腹嬮時 & 靜常時 & 加腹筷時 \\
\hline 1 & 佐O & & 9 & 33 & 結核性萎縮膀胱 & 200 & 12 & 60 & 43 & 70 \\
\hline 2 & 秀O & & 8. & 31 & 膀 胱 腟 瘻 & 500 & 8 & 48 & 24 & 52 \\
\hline 3 & 櫻 & & 9 & 50 & 子 宮 & 200 & 6 & 13 & 15 & 25 \\
\hline 4 & 渡○ & & $\hat{o}$ & 26 & 結核性萎縮膀胱 & 400 & 13.5 & 32 & 24 & 45 \\
\hline 本均 & & & & & & & 9.9 & 38.5 & 26.5 & 48.0 \\
\hline
\end{tabular}

第 3 表 直腸內壓及び膀腃內壓測定值

\begin{tabular}{|c|c|c|c|c|c|c|c|c|c|c|c|}
\hline \multirow{3}{*}{ 番號 } & \multirow{3}{*}{ 被 檢 者 } & \multirow{3}{*}{ 年齢 } & \multirow{3}{*}{ 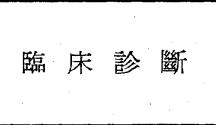 } & \multicolumn{4}{|c|}{ 直腸 $(\mathrm{mmHg})-300 \mathrm{cc}$} & \multicolumn{4}{|c|}{ 膀胱 $(\mathrm{mmHg})-300 \mathrm{cc}$} \\
\hline & & & & \multicolumn{2}{|c|}{ 背 位 } & \multicolumn{2}{|c|}{ 立 位 } & \multicolumn{2}{|c|}{ 背 位 } & \multicolumn{2}{|c|}{ 立 位 } \\
\hline & & & & 靜常時 & $\begin{array}{l}\text { 加腹 } \\
\text { 壓時 }\end{array}$ & 靜常時 & $\begin{array}{l}\text { 加腹 } \\
\text { 壓時 }\end{array}$ & 靜常時 & $\begin{array}{l}\text { 加腹 } \\
\text { 壓時 }\end{array}$ & 静常時 & $\begin{array}{l}\text { 加腹 } \\
\text { 擘時 }\end{array}$ \\
\hline 1 & 笹 0 & 59 & 前立腺肥大症 & 12 & 50 & 23 & 51 & . & & & \\
\hline 2 & 加 0 & 22 & 精 系靜 脈 瘤 & 6 & 33 & 15 & 56 & & & & \\
\hline 3 & 㐫 0 & 42 & 結 & 5 & 37 & 16 & 60 & & & & \\
\hline 4 & 西 0 & 59 & 前立腺肥大症 & 5 & 50 & 17 & 60 & & & & \\
\hline 5 & 岩 $\bigcirc$ & 20 & 結 & 8 & 17 & 13 & 47 & & & & \\
\hline 6 & 水 0 & 62 & 膀 胼 㮩 室 & 16 & 82 & 25 & 85 & & & & \\
\hline 7 & 江 0 & 34 & 㙠 結 核 & 20 & 70 & 23 & 75 & & & & \\
\hline 8 & 黑 $\bigcirc$ & 63 & 前立腺肥大症 & 13 & 66 & 26 & 80 & & & & \\
\hline 9 & 佐 0 & 62 & 膀 脱 腫 瘍 & 25 & 85 & 28 & 95 & & & & \\
\hline 10 & 帆 0 & 31 & $\begin{array}{lll}\text { 腎 } & \text { 結 } & \text { 核 } \\
\end{array}$ & 12 & 70 & 25 & 82 & & & & \\
\hline 11 & 宇 0 & 33 & 副睪 丸 結 核 & 25 & 63 & 27 & 63 & 7 & 47 & 22 & 83 \\
\hline 12 & 柳 0 & 50 & "I & 8 & 55 & 17 & 105 & 4 & 28 & 18 & 75 \\
\hline 13 & 右 0 & 37 & 腎 & 7 & 58 & 23 & 85 & 11 & 65 & 24 & 120 \\
\hline 14 & 渡 0 & 25 & 11 & 7. & 33 & 25 & 42 & 4 & 33 & 18 & 42 \\
\hline 15 & $\equiv 0$ & 35 & 尿 管 結 石 & 10 & 36 & 26 & 53 & 5 & 35 & 22 & 83 \\
\hline 16 & 小 0 & 29 & 副 睪丸 結 核 & 12 & 56 & 28 & 95 & 6 & 35 & 25 & 80 \\
\hline 17 & 神 0 & 24 & 腎 孟 結 石 & 7 & 90 & 25 & 103 & 6 & 80 & 14 & 88 \\
\hline 18 & 近 0 & 28 & 尿 管 結 石 & 12 & 68 & 35 & 70 & 4 & $7 \overline{3}$ & 25 & 95 \\
\hline 19 & 安 0 & 23 & 副睪丸結核 & 12 & 68 & 26 & 72 & 7 & 58 & 19 & 93 \\
\hline 20 & 長 0 & 21 & 腎 孟 結 石 & 6 & 68 & 25 & 96 & 8 & 32 & 23 & 53 \\
\hline 平均 & & & & 12.0 & 58.0 & 24.0 & 74.0 & 6.0 & 48.0 & 21.5 & 76.3 \\
\hline
\end{tabular}

る. 郎ち, Hurstによれば，直腸の平均內壓は靜 時には $27 \mathrm{~cm}$ 水柱(約 $20 \mathrm{mmHg}$ )であるが，それが $54 \sim 68 \mathrm{~cm}$ 水柱(約 $40 \sim 50 \mathrm{mmHg}$ )になつて始めて 排便感がょこり，次いで排便時には $270 \mathrm{~cm}$ 水柱 （約 $198 \mathrm{mmHg}$ ）迄上昇する. 又 Best and Taylor によればその值は靜時には約 $20 \mathrm{mmHg}$ 尚るが， 排便時には40〜 $50 \mathrm{mmHg}$ に上杽するという．私の 测定值は大體に於てこの兩報告と平行するが秒了 低い。これは曂置した S 狀腸であると云う異つた 條件によるものと考えられる。

(八) 直 腸

私は曂置しない普通の直腸の內壓を尿管腸吻合 術を施行しない：種々の患者20例について測定し て見た.なおこの際に, 直腸內の狀態が比較的 $\mathrm{S}$
第 4 表 膀腅容量による膀胱內镸の變化

\begin{tabular}{|c|c|c|c|c|c|c|c|c|}
\hline \multicolumn{3}{|c|}{ 容量 (cc) } & 50 & 100 & 150 & 200 & 250 & 300 \\
\hline \multirow{3}{*}{$\stackrel{\text { 內 }}{(\mathrm{mmH})}$} & \multirow{2}{*}{ 背位 } & 佐藤 & 1.72 & 2.65 & 3.49 & $9 \mid 4.23$ & 5.22 & 6.15 \\
\hline & & 鈴木 & 1.5 & 2.7 & 2.9 & 3.2 & 4.6 & 6.0 \\
\hline & & & 14.6 & & & & & \\
\hline
\end{tabular}

狀腸膀胱の場合に近い樣にと考虑して，隇菌水の 注入を大體 $300 \mathrm{cc} て ゙$ 打切つた。 その值は第 3 表に 示す如く，既に述べた S 狀腸膀胱よりは高く，大 體Hurst 及び Best and Taylor の報告に一致す るものである.

(二) 膀 胱

直腸內壓を測定した 20例の中膀胱疾患のない10 
例では，同時に膀胱內壓をも背位及び立位の辀常 時及び加腹壓時の4つの場合に互つて测定した。 立位の膀胱內壓の测定は從來問題がある處で, 特 に零黙のとり方が六ケ敷いが，私は恥骨上緗にと つて見た.この测定法は深く考えれば色々問題は あるが私は立位に於ける值腸內壓と比較するため にあえて測定したのである。

立位に於ける膀胱內壓值に關しては餘り報告が ないが, 最近 Bauer 泣立位ではその值が背位の 場合の $3 \sim 4$ 倍であると述べている.

私の测定值は，第 3 及び 4 表に示す如く，背位 靜常時では大體佐藤の報告に一致している.この 傎は加腹壓時，特に立位加腹壓時には豫想外に上 昇した. そして各條件のもとに於ける膀胱內壓を 直腸內壓と比してみると，大體に於いて背位䧧常 時には膀胱內壓は面腸內壓より低いが，立位の加 腹壓時の內壓は殆んどこの网者の間に装異になか つたことが制つた。 ただし既に述べた如く，臬腸 內壓の測定時には注入液體を $300 \mathrm{cc}$ 乙限定したか ら，實際の內壓はこの測定値を上迎ることが豫想 される.

\section{IV. 考按}

趣腸膀胱が $\mathrm{S}$ 狀腸膀胱及び尿管 $\mathrm{S}$ 狀腸敂合術後 に比較して血液電解質が㨢めて安定している事 は，以上の腸內壓の测定值と結び合せて考えて見 ると，極めて興味ある結論が得られる．郎ち，腸 內壓の測定値を見ると次の三つの注目す心き事實 がある. 第 1 に备腸膀胱內壓は背位靜常時には勿 諭のこと，特に立位加腹壓時にも面腸內壓よりも 格段に低いことである.そして第 2 に，直腸內壓 は喛置しても然らざる場合と餘り變りなく高い事 である. その事實は全く, 越腸膀胱では血液電解 質が安定しているのに對して，S 狀腸內に尿を導 く時には同部を曂置しても血液電解質の點から餘 りよくなつていない事實と平行するもので，尿管 腸吻合術後の電解質の不平衡は吻合部腸管の高い 內壓のための腎障碍がその大なる原因をなす事を 寒書きしている. 術後婜障碍の今一つの原因とさ れている上行性感染に就て見るに（詳細は高野成 夫が發表した)，この方面から考えれば趣腸膀胱
己 $\mathrm{S}$ 爿腸膀胱は普通の尿管の爿晹吻合術と比較 して殆んど同程度に無菌に近く，從つて衔後の血 液電解質の妿定度も同程度であつてよい筈である が，實際には既に述へた如く，S 狀腸膀胱は普通 の尿管 S 狀腸叨合術と同樣にその安定度が低いの だある．故に尿管腸吻合衍之同樣その安定度が低 いのである．故に尿管腸吻合術後の血液電解質の 安定しているためには，吻合部腸內壓が低い事が 絕對に必要であつて，その腸內細菌感染の程度は 直接には左程の影響加ないと考えられる。 そして 趣腸膀胱はこの點で理想的な安定した疗管腸吻合 術で，この利點は尿掼のために堛尿器を裝置しな けれ音なるい缺點を補つて餘りあるものであ る.

最後に膀胱內壓も立位加腹壓時には宜腸內壓之 同樣に高い點について考えて見よ.う.

正常尿管の蠕動は尿管口迄及んで尿を膀胱內に 絞り出すのであるから，膀胱內壓は直接に上部尿 路に波及しないし，又膀胱の高い內壓に打ちかつ て尿が膀胱に流入し得る。しかし，尿管 S 狀腸吻 合術後には，この樣な自然の尿管口部の腸內壓に 打ち勝つ裝置がないから，膀胱內壓と同高の內壓 も面ちに上部尿路に波及するもので，本手術に腎 瘦から兴便及び瓦斯が流出するとか（Whisenand and Moore), 自發性氣體腎血像を見るとか( $\mathrm{Ma}$ this), 或㥀腸內に注入した造影劑の上部尿路え の逆流像を見る(Baker and Miller)等が起るので このためである. 文この內壓に打勝つ程に尿管口 部を屈曲するなり，或は締めつければ皮腎症がお こる危險があるから，事情は全く膀胱の場合と異 るものである. 故に尿管腸吻合術後には正常膀胱 よりも內壓が一層低い事が要求される。

\section{V. 結 論}

私は臨床例について各種尿管腸吻合衍後の腸內 壓测定法己同樣の方法で测定して，次の結果を得 た.

1. 䞤腸膀胱內壓は ( 7 例の平均)，背位靜常時 $に 1.9 \mathrm{mmHg}$, 及び加腹壓時に $5.8 \mathrm{mmHg}$, 立位静 常時に $5.9 \mathrm{mmHg}$ 及び加腹壓時に $9.6 \mathrm{mmHg}$ 己嫩 あて低壓であつた。 
2. S 狀腸膀胱內壓 ( 4 例の平均) は背位静常時 に $9.9 \mathrm{mmHg}$ 及び加腹壓時に $38.5 \mathrm{mmHg}$ ，立位 静常時に $26.5 \mathrm{mmHg}$ 及び加腹壓時に $48.0 \mathrm{mmHg}$ 之可成り高壓であつた。

3. 正常值腸內壓 (20例の平均) は背位靜常時に $12 \mathrm{mmHg}$ 及び加腹壓時に $58 \mathrm{mmHg}$, 立位靜常時 に $24 \mathrm{mmHg}$ 及び加腹壓時に $74 \mathrm{mmHg}$ で，膀胱內 壓は (中10例の平均)夫々 $6.0 \mathrm{mmHg}, 48.0 \mathrm{mmHg}$ ， $21.5 \mathrm{mmHg}$ 及び $76.3 \mathrm{mmHg}$ であつた. 郎ち， 膀胱內壓は背位靜常時には直腸內壓よりも秒ら低 いが，立位加腹壓時にはこの兩者は殆んぞ同樣の 高さに上昇する.

4. 趐腸膀胱に於て血液電解質が㚣定している のは，腸內壓が低くて婜障碍の起らないためであ

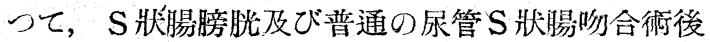
の血液電解質の不安定は直腸內壓の高いためにお こる繁障碍によると考光られる。

5. 尿管腸吻合術後の血液電解質の安定には吻 合部內壓の低い事が最も必要子條件で，晹の細菌 感染程度淔接の影響はない。
文獻

1) Baker, R. and Miller. G. H.: J. Urol. 67, 638, 1952.

2) Bauer, R.: Z. Urol. 44, 753, 1951.

3) Best, C. H. and Taplor, N. B. : The physiological Basis of Medical practice, Baltimore: Williams and Wilkins, 1950, 5th ed.

4) Boyce, W. H. and Vest, S. A.:J. Urol. 67, 169, 1952.

5) Bricker, E. M.: Surgery, 32, 372, 1952.

6) Eiseman, B. and Bricker, E. M.: Ann. Surg, 136, 761, 1952.

7) Hurst, A. F.: Quoted by Boyce and Vest.

8) Kekwick, A., Paulley, J. W., Riches, E. W. and Semple, R.: Brit. J. Urol. 23, 112, 1951.

9) Klinge, F. W. and Bricker, E. M.: Ann. Surg. 137, 36, 1953.

10) Korenberg, M.: J. Urol. 66, 686, 1951.

11) Mathis, R. I.: Rev. argent. de Urol. 16, 229, 1947.

12) McLean, D. W. and Fais, O. G.: J. Urol. 68, 190, 1952.

13) Mersheimer, W. L., Kolarsick, A. J. and Kammandel, H.: Proc. Soc. Exper. Biol.\& Med. 76, 170, 1951 .

14）佐藤誠：日泌瓜會誌, 29, 445, 1940.

15) Whisenand, J. M. and Moore, V.: J. Urol. 65, 564, 1950. 